$\xi=-1$

\title{
Measuring Young Professionals' Housing Affordability in Greater Kuala Lumpur
}

\author{
Nor Suzylah Sohaimi ${ }^{1 *}$, Alias Abdullah ${ }^{2}$, Syafiee Shuid ${ }^{3}$ \\ ${ }^{I}$ Department of Planning and Property Development, School of Government, College of Law, Government and International Studies, \\ Universiti Utara Malaysia, Malaysia \\ ${ }^{1,2,3}$ Kulliyyah of Architecture \& Environmental Design, International Islamic University Malaysia \\ *Corresponding author E-mail: suzysohaimi@gmail.com or suzysuhaimi@uum.edu.my
}

\begin{abstract}
A plethora of approaches applied for measuring the housing affordability. Undoubtedly, the housing cost and household income are ubiquitous predictors to address the housing affordability. Besides, housing policies also receive an enormous attention in debating this issue. This study, therefore, presents the predictors of transportation cost along with other factors in addressing housing affordability for young professionals. Equally, important, individual life event is also highlighted as this matter is being given less attention. By adopting these dimensions, it is idyllic in associating the study gap. Young professionals are individuals aged between 25 and 35 years old and either working or living in Greater Kuala Lumpur with at least a bachelor's degree qualification and registered through the professional firm. The purpose of the study is first, to measure young professionals' affordability by underpinning the residual income approach and second, to explore the affordability through the housing trajectories concept. Thus, 290 survey data were analysed using the binary logistic regression. The study found that the predictors such as the presence of children, professional for engineer and quantity surveyor, employment status of permanent and other, household expenditure, household income, housing cost, transportation cost, housing location of Petaling Jaya and Putrajaya, are statistically significant to the housing affordability.
\end{abstract}

Keywords: Affordable House, Housing Affordability, Housing Trajectories, Residual Income Approach, Young Professionals

\section{Introduction}

Housing issue in local context has been disputed since 1971. The Malaysia housing provision system can be distributed into four phases starting with Housing the Poor (1971-1985), Market Reform (1986-1997), Slums Clearance (1998-2011) and State Affordable Housing (2012 to present) (1) However, the affordable house issue in early 2012 considerably emphasised on the middleincome earner. This statement is supported with an assertion that at the phase of State Affordable Housing, the housing provision system must address the middle-income people by reducing the number of public and private low cost housing provisions (2). As observed at the initial Malaysia housing policy, the public sector has been enhanced and encouraged for the low cost housing provision and only in 2012, the middle income housing affordability had been addressed.

Furthermore, the contemporary studies have emphasised on housing affordability among different income groups instead of different generations, hence the lack of attention in generation affordability (3). Now, the study of generation affordability for housing has emerged and received attention, and various scholars have used numerous terminologies to refer to young generation, for instance Gen Y (3), young starters (4), young couple (5) and young working households6. Following these studies, the terminologies of young generation were not derived from certain age range, except Gen Y has been referred technically to individuals born from 1979 to 1994 . This study, therefore, focuses on specific young generation namely as young professional aged 25 to 35 .
To date, numerous barometer of housing affordability has emerged $(7,8)$. Some involve the housing cost approach, and some use the basic non-housing cost approach. About this matter, 'talk of housing affordability is plentiful, but a precise definition of housing affordability is at best ambiguous' (9). This study, therefore, is merging the economy and social approaches. Firstly, the economy approach employed the residual income approach while the housing trajectories concept is used to represent the social approach. Turning to economy approach, most of the previous studies overlooked the transportation cost in measuring housing affordability. This point has been devastatingly critiqued and considering that the contemporary housing affordability barometer merely emphasis on the housing cost and income instead of undertaking transportation cost in measurement (10). This study, therefore, fills the gap by considering the transportation cost in residual income approach as well as other predictors that were being tested.

Secondly, the social approach is considered the housing consumption over the life event. In this respect, the young professionals' life event has explored and identified how each event influences them in making a housing decision specifically in housing affordability. Thus, the context of social approach is more deepen with the inclusion of housing pathways and housing transition concepts The study is becoming better than to rely on the single approach of residual income. Many other prominent social scholars are arguing that numerous current housing studies ignore the sociological approaches $(11,12)$. Therefore, by merging these approaches, this study accomplished to answer the research objectives of identifying housing affordability factors by conducting questionnaire survey and interview. 


\section{Literature Review}

\subsection{Young Professional Definition}

Young professional is defined by enlightening the words of 'young 'and 'professional'. Firstly, the age of young cohort is the vital criterion to express the subject. Many international scholars and organisations have employed the young groups in various studies. However, they were not explicitly addressed as young groups but applied to a diverse of age groups. The United Nation for instance, describes a young group or also known as "youth" as generation aged from 15 to 24 but accepting other range which not later than 35 (13) and this range has been adopted by others (14). Meanwhile, some the Association of Canadian Community College (ACCC) has used a slightly wider range, from 18 to 34 to address the young (15). Briefly, from the global view, young generation referred in the range of 15 to 24 and some up to 35 .

Nevertheless, Malaysia has an opposite view to this, which the National Youth Societies (1985) previously created the range from 15 to 40 . Eventually, this wider range is supported and applied by many local organisations and scholars such as in the National Youth Development Policy in 1997. Furthermore, some agreed that this range is ideal to define the young generation as this range influences much on political aspect as voters, social as symbolising unity and economical as human capita (16). This fact is also gazetted in the Youth Societies and Youth Development Act (2007) which addresses that young generation is pointed to individuals not less than $15 \mathrm{~s}$ and not exceeding 40 (17).

Although the range of age from 15 to 24 is accepted broadly at the international level, while the age accepted for local context is at 15 to 40 . However, does this range appropriate to address young generation, especially for certain issues like housing affordability of young generation? Undoubtedly, the range of young generation as discussed above is questionable. A few local scholars have provided some different dimensions. For example, some argued that the young age range should be classified into 15 to 35 and 15 to 30 and 15 to 25 (until the range accepted), which the range should change in tandem with time passage ${ }^{18}$. However, the idea to divide the young range into three groups as proposed is seemed ideal which the range divides into early youth [15-20], middle youth [21-24] and late youth [25-35] (19). Also, to strengthen this argument, Mustari's perspective can be considered, which refers the youth in higher education with the age from 18 to 25 and that indirectly, the young would start their career at the age of 25 (20). The term 'professional' referred as an individual qualified in a profession and specified activity as well as resulted in a better income than an unskilled employee (21). Besides that professional also defined as a firm definition to portray the character of working phase recognised as good attitude, skills and knowledge for good performance (22-24). Professional is obligatory for specialised training and development which require lengthy training $(23,24)$. This group is also controlled and regulated by the autonomous professional institute.

With regards to this study, a young professional is devoted to graduate with a minimum of bachelor degree at the age from 25 to 35 . The young professional in the study is subject to the certain profession in the built environment background namely engineer, architect, urban planner and quantity surveyor, where they are regulated by respective professional institutes. In the local practices, most of the bachelor degree holders would graduate as early as the age of 22 or 23 , but architecture graduates would finish a little later. Therefore, the study adopted Hamzah's classification of the young age range, 25 to 35 (19). Table 1 below shows a summary of the literature review for young professional definition by various scholars.
Table 1: Summary of the young age range

\begin{tabular}{|c|c|c|c|}
\hline $\begin{array}{l}\text { Author/ } \\
\text { Organisa- } \\
\text { tion }\end{array}$ & $\begin{array}{c}\text { Ap } \\
\text { plie } \\
\text { d } \\
\text { Ter } \\
\text { m }\end{array}$ & $\begin{array}{l}\text { Suggestion age } \\
\text { of young }\end{array}$ & Others \\
\hline $\begin{array}{l}\text { United } \\
\text { Nation } \\
\text { (UN) }\end{array}$ & $\begin{array}{l}\text { Yo } \\
\text { uth }\end{array}$ & $\begin{array}{l}-15 \mathrm{~s} \text { to } 24 \mathrm{~s} \\
-\quad 10 \mathrm{~s} \text { to late } 30 \mathrm{~s} \\
\text { (some cases) }\end{array}$ & $\begin{array}{l}\text { Young age is a } \\
\text { transition from child- } \\
\text { hood to adulthood }\end{array}$ \\
\hline $\begin{array}{l}\text { National } \\
\text { Youth } \\
\text { Policy } \\
\text { India } \\
\text { (2014) }\end{array}$ & Nil & $15 \mathrm{~s}$ to $29 \mathrm{~s}$ & $\begin{array}{l}\text { Young age determina- } \\
\text { tion is frequent chang- } \\
\text { es. }\end{array}$ \\
\hline UNESCO & $\begin{array}{l}\text { Yo } \\
\text { uth }\end{array}$ & $\begin{array}{l}\text { Adopted the } \\
\text { UN's definition } 15 \mathrm{~s} \text { to } 30 \mathrm{~s} \\
\text { (for local community } \\
\text { youth program) }\end{array}$ & $\begin{array}{l}\text { Youth refers to those } \\
\text { has to finish compulso- } \\
\text { ry educations and } \\
\text { started first job. }\end{array}$ \\
\hline $\begin{array}{l}\text { Associa- } \\
\text { tion of } \\
\text { Canadian } \\
\text { Commu- } \\
\text { nity Col- } \\
\text { leges }\end{array}$ & $\begin{array}{l}\text { Yo } \\
\text { ung } \\
\text { Ad } \\
\text { ult }\end{array}$ & 18 s to $34 \mathrm{~s}$ & $\begin{array}{l}\text { ACCC denied some } \\
\text { range age of young } \\
\text { people. }\end{array}$ \\
\hline $\begin{array}{l}\text { Schizzerot } \\
\text { to \& \& } \\
\text { Gasperoni } \\
(2001)\end{array}$ & Nil & $15 \mathrm{~s}$ to $24 \mathrm{~s}$ & Nil \\
\hline $\begin{array}{l}\text { National } \\
\text { Youth } \\
\text { Societies, } \\
\text { Malaysia } \\
\text { (1985) }\end{array}$ & & $15 \mathrm{~s}-40 \mathrm{~s}$ & Nil \\
\hline $\begin{array}{l}\text { National } \\
\text { Youth } \\
\text { Develop- } \\
\text { ment } \\
\text { Policy } \\
\text { (NYDP) } \\
\text { (1997) }\end{array}$ & Nil & $15 \mathrm{~s}-40 \mathrm{~s}$ & Nil \\
\hline $\begin{array}{l}\text { A. Bahari } \\
\text { (1995) }\end{array}$ & $\begin{array}{l}\text { Yo } \\
\text { uth }\end{array}$ & 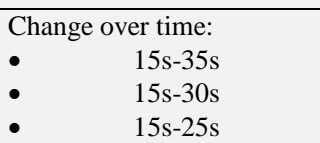 & $\begin{array}{l}\text { The range } 15 \mathrm{~s}-40 \mathrm{~s} \text { is } \\
\text { extensive and } \\
\text { inappropriate }\end{array}$ \\
\hline $\begin{array}{l}\text { Hamzah } \\
\text { et al. } \\
(2007)\end{array}$ & $\begin{array}{l}\text { Yo } \\
\text { uth }\end{array}$ & 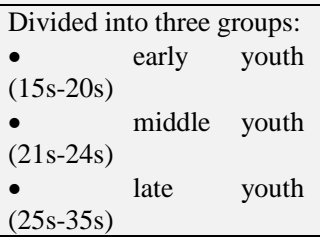 & \\
\hline
\end{tabular}

Source: This study (2018)

\subsection{Housing Affordability Approaches}

Numerous of housing studies specifically in affordability issues are expressed merely in economic perspective either on housing cost or non-housing cost and some articulated the policies perspective to challenge the issue. The combination between economic and sociology approaches provides comprehensive view of the housing affordability study.

\subsubsection{Economic Perspective}

Two main approaches globally debating on housing affordability measurement, namely house price-to-income ratio (PIR) representing housing cost approach and residual income representing necessary non-housing cost approach. Firstly, the PIR is assuming that the household capable of allocating $25-30 \%$ of household 
income for housing cost. This conventional approach was rooted in American view in the 1930s where the household should be devoted a standard of maximum proportion of income for housing costv (25). Although the PIR is the most conventional approach, it is accepted by worldwide practitioners $(26,27)$ and considered the most ordinary method (28). This approach merely is computed and apprehended $(7,29,30)$. Besides, it is beneficial for comparative research (30) and for example, this method is valuable to measure the relative position in the housing system by the various groups in Australian study (31).

Besides providing advantages in measuring affordability, PIR is also receives critics in a lot of studies. The most vital of these criticisms is that the benchmark of $25-30 \%$ as a standard income for housing cost is dubious, as previous scholars also claimed that it is a descriptive method and present enormous issues $(30,9)$. Furthermore, PIR ignores the household financial constraints. The household might able to allocate the proportion for housing cost but neglect to meet the minimum standard of living and potentially fall into poverty line. In the similar vein, some argued that the cost of living between various locational is varied ${ }^{8}$. Besides, it is inappropriate for a household who prefers high housing consumption, which causes high house price-to-income ratio 28,32. A 'rule of thumb' of $25-30 \%$, therefore is debatable in measuring housing affordability.

Alternatively, the residual income is seen more substantial as this method is concerned to meet the minimum standard of living. With regard to this matter, the 'poverty' standard had been used in the residual income instead of certain percentage as the PIR employed (33). Meanwhile, in some study, the shelter poverty standard had been employed, for instance, the household would experience shelter poverty or housing stress when the disposable income after paying the housing cost is below the relevant living standard (34). This method as the adequacy of disposable income to allocate for other necessities in the market basket after paying the housing cost, and then the household are considered as meeting affordability (28). The residual income method improved from the primitive method namely market basket (35) and shelter poverty method (36).

Equally important, the residual income method is sensitive to household structure and various income levels (33) as it appears as a sliding scale of housing affordability. In contrast, the PIR miscarried the diversity of household and household expenditure patterns (30). Likewise, the most recent study also criticised the PIR due to failure to express the diversification of household size and composition as these aspects emerging to a substantial variance to affordability (38). In comparison, the residual income is competent to close the PIR weakness. For instance, if the PIR principle is used to measure affordability, therefore, the household without children is more likely affordable to allocate $30 \%$ of income on housing cost compared to the household with children and similar household income.

By using the residual income approach, the below equation is used. The equation explains that the young professional would reach affordability when the disposable income indicates positive amount after utilising monthly housing cost, household expenditure and unaffordability is vice versa. The equation is as follows:

\begin{tabular}{|llll|}
\hline $\begin{array}{l}\text { Housing } \\
\text { Affordability }\end{array}$ & $\begin{array}{l}\text { Monthly } \\
\text { Household } \\
\text { Income }\end{array}$ & $-\begin{array}{l}\text { Monthly } \\
\text { Housing } \\
\text { Cost }\end{array}$ & $-\begin{array}{l}\text { Monthly } \\
\text { Household } \\
\text { Expenditure }\end{array}$ \\
\hline
\end{tabular}

Fig 1: The equation of housing affordability

\subsubsection{Sociological Perspective}

As aforementioned, sociological theory is the least attention or it merely takes a cross-sectional perspective in the housing studies. This study, therefore, filled the gap involving the social view associated with the economic view. In this respect, housing over the life course concept emphasised and discussed, by which the con- cept comprises housing histories (39), housing careers (40), housing pathways (11) and housing transitions (41). By employing the concept, the young professionals lives' experience explored towards housing affordability. For instance, the process commences after the young professionals finish the university and enter occupation phase, and simultaneously seeking for house either for homeownership or shared rental. All these processes were discovered to answer how the factors of the life courses influence housing affordability among the young professionals.

Nevertheless, only two concepts of housing trajectories engaged in the study, namely housing pathways and housing transitions. The concept of housing career was linked linearly to the career status (40). In this respect, a series of moves into progressively better dwelling supported career success. This point, however, receives devastatingly criticism as this concept is merely considered the capital growth and career success leads to a higher level of housing satisfaction (41) and not all households are fortunate in career success (42). The second concept, housing history seems more significant than housing career. This concept embraces multiple structural factors namely location, ethnicity, and gender (43), where these aspects are absent in housing career. Additionally, the living location, household income and accommodation subsidies determine the homeownership decision (44).

Although the housing history is greater than housing career, the housing pathways have been better from these both concepts (45). The housing pathways differ from others as it is not only considered the individual life experiences towards the homeownership but importantly considers the housing market (42). However, most current housing researchers do not pay attention to address on two aspects namely the set of organised arrangements that form behaviours in the housing market and agency aspects (decision, values and individual experiences and households) (42). To elaborate, the housing pathways emphasise on the process of household's interpretation and understanding their progression over the housing system (42). Briefly, the housing pathways are being upgraded from housing career. The housing pathways include all the aspects and add the meaning attached to the dwelling, the relationship with the life course and connections within the locality. In contrast, the housing career assumes the household has an upward trajectory.

All the three concepts address the relationship between household and housing outcomes through the life course. Housing history has added the factors such as demographic, income, locality, social 'meaning' attached to a dwelling, and policy and subsidies are reflecting this relationship. However, Clapham's work provides greater depth of comprehension of household interaction with the housing market. Meanwhile, the housing transition has been presented and provides some different views as this concept emphasises on propensities in housing decision throughout the life course. Five factors reflect housing decision namely demographic, aspiration, employment, housing history and health (41). In this respect, the housing pathways and housing transition engaged in this study, by which the young professionals' life course is explored. As an example, the young professionals in the early life course who just finished the tertiary education, landed a job, and being married can become vital aspects of housing choices. Besides, other factors such as locational preferences and lifestyle might influence the young professional in making a decision. Therefore, all these factors from sociological perspective show how it influences the housing decision towards affordability.

\section{Methodology}

The unit of analysis for the study is young professionals with at least a bachelor's degree and aged from 25 to 35. Another criterion, they either work or live in Greater Kuala Lumpur. This study is restricted among professionals from the first layer of built environment professionals namely the engineer, architect, urban planner and quantity surveyor. All these professionals obtained 
their professional status from professional institutions such as the Institution of Engineers Malaysia (IEM), Malaysian Institute of Architects (MIA), Malaysia Institute of Planners (MIP) and Royal Institution of Surveyor Malaysia (RISM). The mixed method was employed, consisting of survey and interview. In this respect, the sampling technique involves a probability technique of stratified random sampling for surveying, while non-probability of purposive sampling is applied for selecting the interview respondents. Meanwhile, the number of sampling size was 290 respondents for the survey and merely four respondents for interview obtained from respective professionals' institutes.

The binary logistic regression was used for analyses, therefore measuring housing affordability involved at two levels where Level 1 represents affordable and Level 0 represents not affordable. The relationship between all predictors towards housing affordability is not a linear function, and the logistic regression function is by the logit transformation of $\Theta$ :

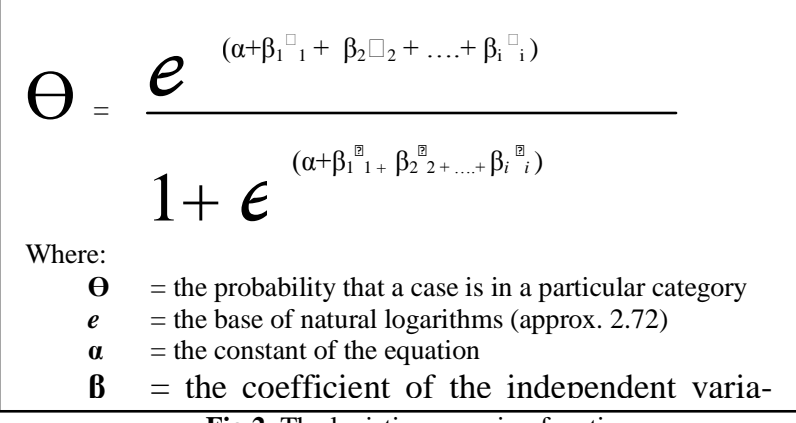

Fig 2: The logistic regression function

\section{Results and Findings}

\subsection{Economy Perspective}

The Table 2 shows the housing affordability for a different type of ownership. The data was generated by employing the equation of the residual income approach (see Figure 1). At first glance, it is noticeable that the renting rate is slightly outnumbering home ownership by 25 individuals. The statistics also prove that the young professionals have the housing affordability and merely 16 renting respectively. Despite that fact, the statistics also show that approximately 105 respondents experience difficulty for buying a and 14 respondents having difficulty for home ownership and house in the near future, where the respondents were from renting market and parental homes. Turning to this question, the respondents have been asked about the prospect of affordable house price, house type and location. Afterwards, all the information are checked through the reputable property website to ensure the availability of such property.

In examining the household expenditure, the data has been divided into different household income groups although the study is deliberately focusing on the young professional group. As aforementioned, transportation cost is always deserted in measuring housing affordability. Interestingly, the descriptive analysis proved that all household income groups indicate the highest expenditure on the transportation. The T20 group records the greater expenditure on transportation about MYR 1793 monthly and this amount is followed by group M40 and B40 with MYR 1253 and MYR 812 respectively. Then, food and beverages became the second most important in household expenditure. However, this indicator stated the highest at amount below MYR 1000 by T20, while M40 and B40 spend approximately MYR 714 and MYR 378 respectively. Other expenses are considered insignificant as they do not reach MYR 400.

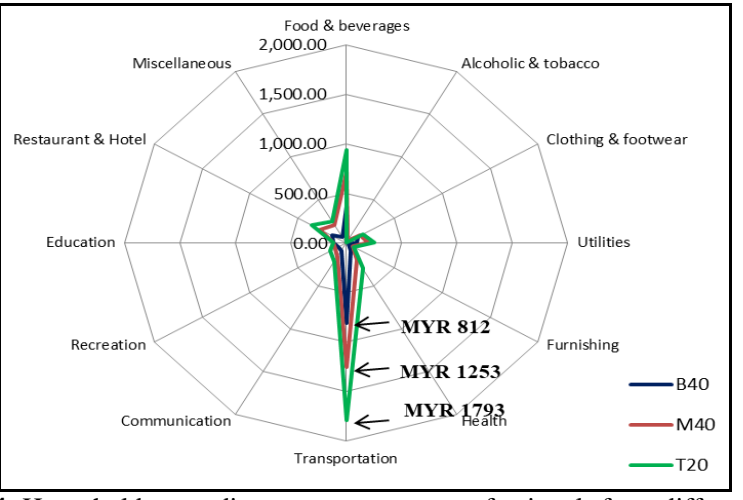

Fig 4: Household expenditure among young professionals from differen household income groups (Source: This study, 2018)

Table 2: Summary of young professionals' housing affordability

\begin{tabular}{|c|c|c|c|c|c|c|c|c|c|c|c|c|}
\hline \multirow{2}{*}{$\begin{array}{l}\text { Profes- } \\
\text { sionals }\end{array}$} & \multicolumn{3}{|c|}{$\begin{array}{c}\text { Homeowner- } \\
\text { ship }\end{array}$} & \multicolumn{3}{|c|}{ Rent } & \multicolumn{3}{|c|}{$\begin{array}{c}\text { Family } \\
\text { Residence }\end{array}$} & \multicolumn{3}{|c|}{$\begin{array}{l}\text { Prospect } \\
\text { Buying }\end{array}$} \\
\hline & $1 *$ & $0 * *$ & $\begin{array}{l}\text { To- } \\
\text { tal }\end{array}$ & $1 *$ & $\begin{array}{c}* \\
*\end{array}$ & $\begin{array}{l}\text { To- } \\
\text { tal }\end{array}$ & $\begin{array}{l}1 \\
*\end{array}$ & $\begin{array}{c}0^{*} \\
*\end{array}$ & $\begin{array}{l}\text { To- } \\
\text { tal }\end{array}$ & $\begin{array}{l}1 \\
*\end{array}$ & $\begin{array}{c}* \\
*\end{array}$ & $\begin{array}{l}\text { To- } \\
\text { tal }\end{array}$ \\
\hline Engineer & 23 & 4 & 27 & 35 & 4 & 39 & & & 14 & $\begin{array}{l}3 \\
1\end{array}$ & 22 & 53 \\
\hline Architect & 32 & 5 & 37 & 23 & 3 & 26 & & & 23 & $\begin{array}{l}2 \\
6\end{array}$ & 23 & 49 \\
\hline $\begin{array}{c}\text { Urban } \\
\text { Planner }\end{array}$ & 11 & 1 & 12 & 28 & 4 & 32 & & & 16 & $\begin{array}{l}2 \\
0\end{array}$ & 28 & 48 \\
\hline $\begin{array}{l}\text { Quantity } \\
\text { Surveyor }\end{array}$ & 10 & 6 & 16 & 17 & 3 & 20 & & & 28 & $\begin{array}{l}1 \\
6\end{array}$ & 32 & 48 \\
\hline Total & 76 & 16 & 92 & $\begin{array}{c}10 \\
3\end{array}$ & 14 & 117 & & & 81 & $\begin{array}{l}9 \\
3\end{array}$ & $\begin{array}{c}10 \\
5\end{array}$ & 198 \\
\hline
\end{tabular}

Table 3 exhibits the logistic regression result, which the twelve predictors indicate a statistically significant improvement through the constant model, model $\square^{2}(14, N=290)$ chi-square $=187.880$, $p<0.05$ with $d f=32$. While the Nagelkerke pseudo R2 showed that the model accounted for 67.8 of variance. Then, the estimation success is considerably high as young professionals who without affordability are $77.9 \%$ while with affordability is $91.7 \%$ and then the percentage of overall accuracy is 87.6. To identify the predictors influencing housing affordability, the significant value is the most important thing to be assessed. The rule of thumb for this matter, the significant value must be less than 0.05 , $(\mathrm{p}<0.05)$. Table 3 indicates that the predictors such as the presence of children, professional for engineer and quantity surveyor, employment status of permanent and other, household expenditure, household income, housing cost, transportation cost, housing location of Petaling Jaya and Putrajaya were the significant contributors to affordability, as all these predictors show the significant value less than 0.05 . Meanwhile, demographic predictor (age, ethnicity, marital status, education level, number of household member), professionals of architect and urban planner, working experience, employment status for contract and temporary basis and other nine housing locations were indicated as not significant in the study.

Table 3: Predictors in the equation

\begin{tabular}{|l|l|l|l|l|l|l|}
\hline Description & Variables & \multicolumn{1}{|c|}{ B } & S.E & Wald & df & Sig. \\
\hline \multirow{4}{*}{ Age } & $25-28$ & & & .656 & 2 & .720 \\
\cline { 2 - 7 } & $29-32$ & .572 & .713 & .642 & 1 & .423 \\
\cline { 2 - 7 } & $33-35$ & .513 & 1.468 & .122 & 1 & .727 \\
\hline \multirow{4}{*}{ Ethnicity } & Malay & & & 2.770 & 3 & .428 \\
\cline { 2 - 7 } & Chinese & .565 & .479 & 1.389 & 1 & .239 \\
\cline { 2 - 7 } & Indian & -.346 & .752 & .212 & 1 & .645 \\
\cline { 2 - 7 } & Others & 2.175 & 2.499 & .757 & 1 & .384 \\
\hline \multirow{3}{\text{Marital}}{} & Single & & & 2.780 & 2 & .249 \\
\cline { 2 - 7 } & Married & 2.317 & 1.509 & 2.358 & 1 & .125 \\
\cline { 2 - 7 } & Divorced & -.966 & 1.909 & .256 & 1 & .613 \\
\hline $\begin{array}{l}\text { Education } \\
\text { level }\end{array}$ & $\begin{array}{l}\text { Bachelor } \\
\text { Degree }\end{array}$ & & & 1.162 & 2 & .559 \\
\hline
\end{tabular}




\begin{tabular}{|c|c|c|c|c|c|c|}
\hline & $\begin{array}{l}\text { Master's } \\
\text { Degree }\end{array}$ & .732 & .679 & 1.162 & 1 & .281 \\
\hline & $\begin{array}{l}\text { Doctor of } \\
\text { Philoso- } \\
\text { phy }\end{array}$ & 21.066 & 27714.132 & .000 & 1 & .999 \\
\hline $\begin{array}{l}\text { Number of } \\
\text { household } \\
\text { member }\end{array}$ & $\begin{array}{l}\text { Household } \\
\text { member }\end{array}$ & 2.259 & 1.309 & 2.975 & 1 & .085 \\
\hline $\begin{array}{l}\text { Presence of } \\
\text { children }\end{array}$ & Children & 3.495 & 1.411 & 6.138 & 1 & .013 \\
\hline \multirow{4}{*}{$\begin{array}{l}\text { Profession- } \\
\text { als }\end{array}$} & Engineer & & & 9.769 & 3 & .021 \\
\hline & Architect & -.764 & .670 & 1.299 & 1 & .254 \\
\hline & \begin{tabular}{|l|} 
Urban \\
Planner
\end{tabular} & .237 & .702 & .114 & 1 & .736 \\
\hline & \begin{tabular}{|l|} 
Quantity \\
Surveyor
\end{tabular} & -1.455 & .616 & 5.585 & 1 & .018 \\
\hline $\begin{array}{l}\text { Year of } \\
\text { working } \\
\text { experience }\end{array}$ & $\begin{array}{l}\text { Working } \\
\text { experience }\end{array}$ & -.262 & .167 & 2.482 & 1 & .115 \\
\hline \multirow{4}{*}{$\begin{array}{l}\text { Employ- } \\
\text { ment Status }\end{array}$} & \begin{tabular}{|l|} 
Permanent \\
\end{tabular} & & & 10.228 & 3 & .017 \\
\hline & \begin{tabular}{|l|} 
Contract \\
\end{tabular} & .782 & .544 & 2.070 & 1 & .150 \\
\hline & \begin{tabular}{|l|} 
Tempo- \\
rary
\end{tabular} & .111 & 1.003 & .012 & 1 & .912 \\
\hline & Others & -6.320 & 2.242 & 7.944 & 1 & .005 \\
\hline $\begin{array}{l}\text { Monthly } \\
\text { household } \\
\text { expenditure }\end{array}$ & $\begin{array}{l}\text { Household } \\
\text { expenditure }\end{array}$ & -.003 & .001 & 13.632 & 1 & .000 \\
\hline $\begin{array}{l}\text { Monthly } \\
\text { household } \\
\text { income }\end{array}$ & $\begin{array}{l}\text { House- } \\
\text { hold } \\
\text { income }\end{array}$ & .002 & .000 & 33.350 & 1 & .000 \\
\hline $\begin{array}{l}\text { Monthly } \\
\text { Housing } \\
\text { cost }\end{array}$ & $\begin{array}{l}\text { Housing } \\
\text { cost }\end{array}$ & -.001 & .000 & 4.121 & 1 & .042 \\
\hline $\begin{array}{l}\text { Monthly } \\
\text { Transporta- } \\
\text { tion cost }\end{array}$ & $\begin{array}{l}\text { Transpor- } \\
\text { tation cost }\end{array}$ & -.002 & .000 & 15.816 & 1 & .000 \\
\hline \multirow[t]{11}{*}{$\begin{array}{l}\text { Housing } \\
\text { Location } \\
\end{array}$} & \begin{tabular}{|l|} 
Kuala \\
Lumpur
\end{tabular} & & & 16.927 & 10 & .076 \\
\hline & Klang & .336 & .837 & .162 & 1 & .688 \\
\hline & Kajang & -1.484 & .844 & 3.096 & 1 & .078 \\
\hline & \begin{tabular}{|l} 
Subang \\
Jaya
\end{tabular} & -.569 & .788 & .522 & 1 & .470 \\
\hline & $\begin{array}{l}\text { Petaling } \\
\text { Jaya } \\
\end{array}$ & 5.353 & 2.426 & 4.869 & 1 & .027 \\
\hline & Selayang & .195 & .931 & .044 & 1 & .834 \\
\hline & \begin{tabular}{|l|} 
Shah \\
Alam \\
\end{tabular} & -.226 & .608 & .138 & 1 & .710 \\
\hline & $\begin{array}{l}\text { Ampang } \\
\text { Jaya }\end{array}$ & -1.181 & 1.108 & 1.137 & 1 & .286 \\
\hline & Putrajaya & -5.661 & 2.039 & 7.704 & 1 & .006 \\
\hline & \begin{tabular}{|l} 
Sepang \\
\end{tabular} & .632 & 1.003 & .397 & 1 & .528 \\
\hline & \begin{tabular}{|l|} 
Others \\
\end{tabular} & -4.607 & 2.543 & 3.282 & 1 & .070 \\
\hline Constant & & 1.268 & 1.469 & .745 & 1 & .388 \\
\hline
\end{tabular}

Source: This study (2018)

\subsection{Social Perspective}

\subsubsection{Housing Trajectories}

Demographic aspect discusses the influence of age when graduated and the presence of child towards housing affordability. All professionals graduated at the age of $23 \mathrm{~s}$ except architect, a slightly late about 25, but all of them were immediately hired. Although architects finished the study later than others, architect prove that they could afford to buy a house at the age of 28 which is similar to other professionals, except the quantity surveyors stated slightly late, at the age of 31 , this also been supported by the survey's result. The relationship between age graduated, and housing affordability is loose. Another finding, a married couple is more likely to become a homeowner compared to the single respondent. The married couple is mostly taking less than two years of marriage to become a homeowner. However, the study also found that QS took longer to become a homeowner, about six years. In this aspect, the presence of children is seen to encourage the head of household to become a homeowner, as they aware about importance of house for well-being creation for the family.

A few aspects discussed to assess the employment factors towards affordability, among others are professional qualification and household income. Intuitively, better education provides pleasant life as this always linked to well-employment and income. In other words, the higher the education level, the better the standard of living. In contrast, the study found that the higher education level does not necessarily promise better living standard as the respondents with master's degree and doctorate experience the difficulty in buying their first house. Another example, a respondent as professional engineer is also struggling to buy a house although has served for seven years in the industry with professional qualification title.

A standard income among young professionals is another imperative point to highlight as it openly associated with affordability. The interview found that all respondents were landing a job easily with a matched career and unemployment does not exist. However, the biggest challenge was the irrelevant initial income received. Table 4 below proves the matter, for example, an architect earned MYR 1300 and additional MYR 300 as transportation allowance in 2013 and almost identical experience encountered by an engineer who only received MYR1500 before an increment to MYR 1800 after a six-month probation period. Interestingly, the urban planner enjoyed with the matched salary rate with MYR 2100 in 2010. Meanwhile, QS started the career with diploma qualification and only earned MYR 700 in 2008 before furthering his bachelor degree shortly and enjoyed the income just below MYR 3000.

Table 4: Initial income for young professionals, from 2008-2013.

\begin{tabular}{|l|l|l|l|}
\hline Professionals & Code & Years & $\begin{array}{l}\text { Initial income } \\
\text { (MYR) }\end{array}$ \\
\hline Architect & $\begin{array}{l}\text { Respondent 1 } \\
\text { (R1) }\end{array}$ & 2013 & $1300+300$ \\
\hline Engineer & $\begin{array}{l}\text { Respondent 2 } \\
\text { (R2) }\end{array}$ & 2010 & 1500 \\
\hline Urban Planner & $\begin{array}{l}\text { Respondent 3 } \\
\text { (R3) }\end{array}$ & 2010 & 2100 \\
\hline QS & $\begin{array}{l}\text { Respondent 4 } \\
\text { (R4) }\end{array}$ & 2008 & $700^{*}$ \\
\hline
\end{tabular}

*Diploma Qualification Source: This study (2018)

According to the housing history, it explains the prior and present occupancy towards housing affordability. The study found that most of the young professionals gave less attention on homeownership while they were in their student pathways, except R4 who desired and had been targeting to own a house at the age of $30 \mathrm{~s}$ since he was at the university. After graduating, some returned to the parental home and some rent with other friends and both merely involve a low rental rate about MYR 250-400 monthly. This amount did not add their burden and they could still afford a shared rental. The affordability issue arises just after they get married, as they are more likely to have privacy. Some respondents such as R1 and R3 were privileged to live in parental homes. The advantage for them is they could secure some deposit for a new house. However, the parental home is insignificant factor as R1 is still cannot afford to buy a house, and R3 had bought a house priced MYR 650,000 and required the parents' assistance to chip in for house deposit. In contrast, R4 who earned a minimum income and survived, neither lived at parental home or receiving parents' assistance, but successfully afford to buy a house priced MYR 450,000 in 2013. The parental home, therefore, is considered as early assistance for young professionals and this factor is not a predominant factor leading to the success of housing affordability.

The health factor towards housing decision is emerging the determinant the type of dwelling occupied, accessibility to care services such as clinic and hospital. However, the health factor does not impact much on housing decision among young professionals as they are considered in good condition or none is having any disa- 
bility or experiencing any chronic disease. In contrast, the mid-life group (aged 50-60s) might need the health facilities much.

Aspiration factor explains about a house decision based on the consumption preferences and other significance aspect attached to the dwelling. In this study, two aspects were discussed, namely housing type and locational preferences. Firstly, the respondents revealed that they would prefer the landed house, but they are not capable of buying landed house in Greater Kuala Lumpur. As an alternative, they rent or buy a high-rise residential type located in Kuala Lumpur. Nevertheless, some respondents have an extreme desire to own a landed house such as R3 and R4, but due to affordability issue they could only afford to buy a landed house located far away (approximately $45 \mathrm{~km}$ ) from their house to workplace in Kuala Lumpur. This house seems to be likely affordable among young professionals as the price is in the range of MYR 350, 000 to MYR 450,000. However, R3 bought a house beyond this range as he has preferences of the remarkable facilities attached to the house. He also stressed that buying a house means 'buying' the environment as well. The group who choose a high-rise house is due to unwilling for inconvenience location. This group prefer the location within a $20 \mathrm{~km}$ radius from their house to workplace, or location with good transportation oriented development.

\section{Conclusion}

Housing affordability in this study refers to affordability either for home ownership or renting. Therefore, if young professionals are having difficulties for homeownership, alternatively they may choose to rent. However, those who is in the parental home, they can choose either renting or buying a house. The finding of this study, however, found that young professionals in parental home choose to live with parents until they could afford to buy a house. Therefore, their affordability is based on purchasing house in the current market shortly after securing jobs.

The descriptive statistics as shown in Table 2 (see Summary of young professionals' housing affordability) indicate that most of young professionals could afford to own houses and only 30 respondents (homeownership and renting) were trapped in difficulty. This declaration excludes the number of respondents in parental home. Despite this fact, 105 out of 198 non-homeowners are stated that they could not afford to buy a house in the near future. This causes them to remain in the rental market and parental home. Undoubtedly that homeownership essential part of well-being creation especially for those just started a family but some are eager to be in the rental market and enjoy their lifestyle. Nevertheless, the finding of this study found that the young professionals are keen for homeownership instead of renting. Therefore, it is alarming to see the number of households who cannot afford to buy a house.

This study also proved that transportation is prominent of household expenditure for all type of household income groups. Beginning with B40 group with a household income below MYR 3860, spending approximately MYR 812 monthly for transportation cost would diminish their capability for homeownership. Another result from this study also indicates that most of young professionals who lived in parental home are in the B40 group. The transportation cost increases in tandem with the increment of household income. This is evident when T20 group reports the highest transportation cost among other groups.

Transportation cost is counted based on monthly consumption of expenses such as petrol, toll, car park, train ticket, maintenance, vehicle instalment, and vehicle insurance. The high vehicle instalment might contribute to the high transportation cost. The statistics of this study reveal that there are three main groups of vehicle instalments targeted by young professionals in the range MYR 0-200 (28\%), MYR 401-600 (22\%), and MYR 601-800 (21\%), followed by MYR 801-1000 (13\%), while vehicle instalment ranges above MYR 1001 is only below $2 \%$ for each. It is certainly irrefutable that vehicle ownership is an essential for young professionals to facilitate in engaging with their profession. Although public transports and private car services do exist, these services are quite costly. Therefore, young professionals certainly need vehicles and then do not be surprised if the hire purchase becomes the initial commitment among them. Sometimes, the question of vehicle ownership is asked in interview sessions by employers for recruitment. In this vein, if young professionals choose the most economical vehicle or low segment, it might lead for housing affordability.

Referring to housing trajectories, the presence of children has encouraged the heads of household to become homeowner. In contrast, the statistics in Table 3 (see Predictors in equation) indicates that the presence of children influences the housing affordability. In this aspect, the presence of children might influence the household expenditure and directly affect housing affordability. However, from different perspective, the children are the alarm for the family to commit into homeownership.

Another compelling point is the standard income level for professional. The result from the survey shows that about 20 respondents still receive an income of MYR 2000 and below. To support this fact, an interview with a young architect who also experiences the low income where he only receives MYR 1300 and additional MYR 300 for transportation allowance in 2013. In this circumstance, a standard income level for young professionals should be developed. With the underpaid situation, the young professionals are struggling to meet their necessities, and intuitively most young professionals who graduated from universities are also burdened with the education debt and no need to mention for housing affordability and homeownership.

\section{References}

[1] Shuid, S,"The housing provision system in Malaysia", Habitat In-

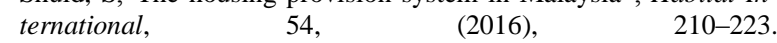
https://doi.org/10.1016/j.habitatint.2015.11.021

[2] Shuid, S.,'Role of the state and market in low cost housing provision in Malaysia: The case study of open registration system for low cost house buyers", (Unpublished PhD thesis Cardiff University Wales). (2011).

[3] Bujang A.A, Anthony Jiram W.R, Abu Zarin H, Md. Anuar F.H,'Measuring the gen Y housing affordability problem". International Journal of Trade, Economics and Finance, 6(1) (2015) 22

https://doi.org/10.1016/j.habitatint.2015.11.021

[4] Zairul, M,'Housing dilemma among young starters in Malaysia". Elixir Sustain, 58, (2013), 14923-14926

[5] Nozin, A.S., Majid, R.A., \& Said, R,'The assessment of expenditure pattern among young couple towards affordability of housing", Annual Postgraduate Seminar, $8^{\text {th }},(2009)$

[6] Zyed, Z. A. S,"Assessment of housing affordability problems among younger working household in greater Kuala Lumpur", (Doctoral dissertation, University of Malaya) (2014).

[7] Belsky E.S, Goodman J, Drew R,"Measuring the nation's rental housing affordability problems". The Joint Center for Housing Studies, Harvard University, (2005).

[8] O'Dell, Smith, M.T, \& White, D,"Weaknesses in current measures of housing needs", Housing and Society, 31(1), (2004), 29-40.

https://doi.org/10.1080/08882746.2004.11430496

[9] Linneman P.D. \& Megbolugbe I.F,'Housing affordability: Myth or reality?", Urban Studies, 29,3/4, (1992), 369-392.

[10] Mattingly K \& Morrissey J, "Housing and transport expenditure: Social-spacial indicators of affordability in Aucland", Cities, 38, (2014), 69-83. http://dx.doi.org/10.1016/j.cities.2014.01.004

[11] Clapham, D, The meaning of housing: A pathways approach, The Policy Press, University of Bristol, (2005).

[12] Sliogeris, E., Crabtree, L., Phipps, P., Johnston, K., \& O’Neill, P. Housing affordability literature review and affordable housing program audit. (2008).

[13] United Nations Population Fund. Framework for action on adolescent \& youth. (2007)

[14] Schizzerrotto, A., \& Gasperoni, G. Study on the state of young people and youth policy in Europe (Vol. 1).IARD, Milan. (2001).

[15] Canada Council on Learning. Health and Learning Environmental Scan (2016) 
[16] Abu.Samah, A.”Emptiness of national youth policy-supporting youth potential through transformation of conflict approach", $M a$ laysian Journal of Youth Study, 1, (2009),1-22.

[17] Government of Malaysia. Laws of Malaysia Act 668, youth societies and youth development Act 2007. (2007). Malaysia.

[18] Bahari. Pergerakan belia: Persoalan dan cabaran. Kuala Lumpur:Institut Kajian Dasar (1995).

[19] Hamzah. A, Krauss S.E, Noah S.M, Suandi T, Juhari R, Manap J,...\& Kassan H. "Muslim Religiosity and Personality Assessment: Prototype for Nation Building". Selangor: Institute for Social Sciences Studies (IPSAS)-University Putra Malaysia, (2007).

[20] Mustari M.I, Menjadi Belia Cemerlang: Belia adalah asset negara yang perlu digilap potensi mereka. Kuala Lumpur. PTS Professional Publishing Sdn. Bhd, (2007).

[21] Professional. (n.d.) In Oxford Dictionaries. Retrieved from https://www.oxforddictionaries.com

[22] Bowl, M.’'Adult Education in Neoliberal Times: Policies, Philosophies and Professionalism". Palgrave Macmillan. (2017)

[23] Flexner, A."Is social work a profession?", In official proceedings of the annual meeting, (1915)

[24] Eraut, M. Developing Professional Knowledge and Competence, Falmer Press. London, (1994)

[25] Feins, J. D., \& Lane, T. S. How much for housing?: New perspectives on affordability and risk. Cambridge, Mass: Abt Books. (1981).

[26] Jewkes, M., \& Delgadillo, L.," Weaknesses of housing affordability indices used by practitioners", Journal of Financial Counseling and Planning, (2010), 43-52.

[27] Robinson, M., Scobie, G. M., \& Hallinan, B. Affordability of housing: Concepts , measurement and evidence (No. 06/03). Wellington, New Zealand. (2006).

[28] Bourassa, S. C,"Measuring the affordability of homeownership", Urban Studies, 33(10), (1996). 1867-1877. https://doi.org/10.1080/0042098966420

[29] Bogdon, A.S \& Can, A, "Indicator of local housing affordability: Comparative and spatial approaches". Real Estate Economics, 25(1), (1997). 43-60.

[30] Hulchanski, J. D,"The concept of housing affordability: Six contemporary uses of the housing expenditure-to-income", Housing Studies, 10(4), (1995). 471-492.

[31] Smith, S. Income, housing wealth and gender inequality. Urban $\begin{array}{lll}\text { Studies, } & 27(1), & \text { (1990). }\end{array}$ https://doi.org/10.1080/00420989020080041

[32] Lerman, D. L. \& R. W. . The affordability of adequate housing. Journal of American Real Estate \& Urban Economics Association, 15(4), (1987). 389-404. https://doi.org/10.1111/1540-6229.00439

[33] Henman, P., \& Jones, A. Exploring the use of residual measures of housing affordability in Australia: Methodologies and concepts. Australian Housing and Urban Research Institute Melbourne, Australia. Mel. (2012).

[34] Stone, M., Burke, T., \& Ralston, L. The residual income approach to housing affordability: the theory and the practice. Melbourne: Australian Housing and Urban Research Institute. (2011)

[35] Grigsby W.G \& Rosenburg, L. Urban Housing Policy.New York: APS Publications,Inc., Center for Urban Policy Research-Rutgers University.(1975).

[36] Stone, M, "Shelter Poverty: New ideas on housing affordability". Temple University Press. (1993). https://doi.org/10.1017/CBO9781107415324.004

[37] Stone, M. E,"What is housing affordability? The case for the residual income approach". Housing policy debate, 17(1), (2006). 151184.

[38] Baker, E., Mason, K., \& Bentley, R. J,"Measuring Housing Affordability: A Longitudinal Approach". Urban Policy and Research, $1146 \quad$ (2015), $1-16$. https://doi.org/10.1080/08111146.2015.1034853

[39] Farmer, M. K., \& Barrell, R, "Entrepreneurship and Government Policy: The Case of the Housing Market", Journal of Public Policy, 1(3), (1981). 307-332.

[40] Kendig, H. L,'Housing Careers, Life Cycle and Residential Mobility: Implications for the Housing Market”. Urban Studies, 21, (1984). 271-283. https://doi.org/10.1080/00420988420080541

[41] Beer, A., Faulkner, D., Paris, C., \& Clower, T. Housing Transitions through the life course: Aspirations, Needs and Policy. Bristol: The Policy Press, University of Bristol. (2011).

[42] Clapham, D,'Housing Pathways: A Post Modern Analytical Framework Housing Pathways: A Post Modern Analytical
Framework", Housing, Theory and Society, 19(2), (2002). 37-41. https://doi.org/10.1080/140360902760385565

[43] Badcock, B.A. and Beer, A, Home truths: property ownership and housing wealth in Australia, Melbourne: Melbourne University Press. (2000)

[44] Forrest, R, "Spatial mobility , tenure mobility , and emerging social divisions in the UK housing market". Environment and Planning A, 19, (1987). 1611-1630. https://doi.org/10.1068/a191611

[45] Clapham, D., Rg, R.,Mackie, P., Avenue, V. I. I., Cf, C., Orford, S. ... Buckley, K. The housing pathways of young people in the UK Environment and Planning A, 46, (2014). 2016-2031. https://doi.org/10.1068/a46273 